\title{
THE EMERGENCE OF INCREASING QUALITY AND MAINTAINING CUSTOMER SATISFACTION IN HIGHER EDUCATION
}

\author{
Oleh : Didik Rinan Sumekto1
}

\begin{abstract}
Abstrak
Saat ini isu seputar mutu pelayanan pendidikan telah menjadi prioritas utama bagi pemangku kepentingan. Beberapa isu berkaitan dengan peningkatan mutu di sektor pendidikan tidak dapat dipisahkan dari aspekaspek utamanya, seperti desain peningkatan mutu yang berorientasi pada mahasiswa sebagai pemangku kepentingan, jaminan dan kontrol mutu terkait dengan pengukuran kepuasan pelanggan yang menekankan pada perencanaan kepuasaan pelanggan di mana produk pendidikan, lembaga pendidikan dan pemangku kepentingannya, dan mutu pembelajaran dilibatkan secara signifikan.

Artikel ini bertujuan untuk mendiskusikan bagaimana mahasiswa di Perguruan Tinggi diposisikan sebagai pemangku kepentingan. Posisi yang dimaksudkan adalah bagaimana pendidikan secara mendasar memerankan fungsinya bagi masyarakat (mahasiswa) yang memiliki hak yang sama untuk belajar. Jaminan dan kontrol terhadap mutu pendidikan berperan membawa mutu pendidikan itu sendiri. Sementara itu, inspeksi dan langkahlangkah pengujian sebagai metode yang paling sering dilaksanakan terkait dengan kontrol mutu dan isu-isu pendidikan untuk menetapkan apakah standarisasi telah dipenuhi atau belum. Jaminan mutu berkaitan dengan desain mutu di mana proses upaya menyakinkan bahwa produk pendidikan dihasilkan atas spesifikasi yang ditetapkan sebelumnya. Maka dari itu, secara konsisten jaminan mutu mengedepankan pemenuhan spesifikasi produk atau melaksanakan hal-hal yang benar di setiap waktu. Sementara itu, pengukuran kepuasan pelanggan memberikan kontribusi kepada Pendidikan Tinggi mengidentifikasi permintaan dan kepentingan mahasiswa secara detil; dan memahami bagaimana mahasiswa memiliki persepsi atas sistem pendidikan yang dijalankan.
\end{abstract}

Kata kunci: peningkatan mutu, kepuasan pelanggan (pemangku kepentingan), jaminan dan kontrol mutu

\section{INTRODUCTION}

Towards the end of the 1990s and into the new millennium, the increased levels of national and international dialogue about the importance of the "quality of education" resulted in decisions by many countries to participate in networks that conducted large-scaled cross-national educational research studies. These studies were aimed at collecting, analysing, and comparing data about the quality of education systems in terms of the general conditions of schooling, the education systems in terms of the general conditions of schooling, the educational achievements of students, and equity in educational provision and outcomes (Ross and Genevois, 2006).

The greater emphasis on the governance of universities from the top level has tended to distract attention within higher education from governance issues lower down in the organization. But, however important probity and accountability issues may be at the governing body, the overall performance of the institution is determined by what happens in academic departments, faculties and by academic decisions

Didik Rinan Sumekto : adalah dosen English Education Study Program Lecturer, Faculty of Teacher Training and Education UNWIDHA 
taken by senates and academic boards. The selection and recruitment of students, the management of academic processes, the conduct of research, the winning of research grants and contracts, the appointment of academic staff-the processes on which the Quality Assurance Agency (QAA) audit success or failure depend on the domain of the academic community and the forms and effectiveness of its decision-making structures provide the framework within which they take place and can determine the effectiveness of their outcomes (Shattock, 2006).

In most of the world, judgements about the quality of education have been an internal affairs placed under the responsibility of educational authorities at governmental and institutional levels. To explain why this is occurring, and why the quality of education has become such a high profile issue, it is necessary to consider several key factors. First, viewpoint about the importance of the quality of education cannot be divorced from the heightened salience of education policy and education reform within the whole range of public policy, mainly because of widely acknowledged linkages between education and economic performance. Second, the nature of the problem has been redefined. Traditional approaches to the quality of education have often relied upon proxy measures, such as increases in financing and other inputs in the level of educational provision. While clearly not irrelevant or unhelpful, such outlays may not prove decisive when another criterion for defining and measuring the quality and education is used, namely: measurable educational outcomes (knowledge, competencies, skills, and behaviours). Third, such question are fuelling a growing trend towards greater interest that has two important dimensions-the first is weather students are learning the right things to lead a decent life in a fast- changing world and the second, which is closely related, concerns monitoring student performance over time, and in a cross-national comparative perspective, in order to provide information for assessing how well, or how badly, educational systems are preparing young people for future adult roles as creative, thinking citizens who can sustain themselves and contribute to the well-being of their families, communities and societies. Fourth, such information is becoming more politically sensitive as it points to unevenness of quality, both within and between education systems. Quality levels vary widely from one education system to another and, within a single education system, there may be sharp variations in quality, for example, between public and private schools, between urban and rural schools, and between education for majority and education for minorities even in the same classrooms male and female students can have significantly different learning experiences. The unevenness of quality is therefore a critical issue facing education systems, and is particularly important as regards the widening economic gap between countries and its impact upon the challenges of development, and the effects of internal disparities on national social cohesion. Fifth, the growing diversification of societies, as a result of migration, urbanization and cultural change and increased sensitivity to individual and group identities, based on national, regional, gender, cultural, ethnic and religious classifications are together placing fresh demands upon education systems, and thereby challenging assumptions about the purposes and functions of education. Issues concerning the quality of education cannot be separated from these trends because they can result in problems of discrimination, racism and violence and these have a major impact on the learning 
environment provided by schools and other learning spaces. The last but not least are about questions that point to the fundamental purposes of education. Disparities in educational quality often mirror other inequalities, which many view as directly tied to the fulfilment of human and other rights. Thus, education is being asked to become one tool, of many, that can build societies based on space, equality and democratic practice.

The understanding of what constitutes the quality of education is therefore evolving. Conventional definitions have included literacy, numeric and life skills, and these have been linked directly to such critical components as lecturers, content, methodologies, curriculum, examination systems, policy, management and administration. However, there is also a demand to reflect upon education's relevance to the modern world, meanwhile in the past much of the emphasis on education related to cognitive understanding and development, is now a need also to address the social and other dimensions of learning. Education is expected to make a contribution to sustainable human development, peace and security, universal values, informed decision-making, and the quality of life at individual, family, societal and global levels (Ross and Genevois, 2006).

\section{INCREASING QUALITY DESIGN}

\section{Defining Quality}

Quality is variously interpreted as an outcome, as a property or characteristic, and as a process (Fraser, 2005). Sallis (2002) distinguishes between quality as fitness for purpose, which is associated with consistent and effectively documented processes, subject to accountability and audit; and what he calls as 'transformational quality' which is 'about improving ... doing things right, not just doing the right things'. Brennan and Shah (2000) use a set of definitions which measures performance and/or outcomes; quality control, which denotes arrangements to verify that teaching and assessment are satisfactory; and quality assurance, which encompasses a system of policies, systems and processes whichmaintain and enhance quality. In designing a quality system it is necessary to recognise the multiple cultures within the university and to develop a system that is balanced between the provision of visible and systematised quality assurance necessary to meet external and internal requirements, and systems that provide significant space for local adaptation such that they are accepted by academics and usefully deployed within different academic cultures. This implies a distributed approach whereby the diverse communities within the university engage with quality issues.

Quality is at the top of most agendas and improving quality is probably the most important task facing any institution. However, despite its importance, many people find quality an enigmatic concept. It is perplexing to define and often difficult to measure. One person's idea of quality often conflicts with another and, as we are all too aware, no two experts ever come to the same conclusion when discussing what makes an excellent school, college or university. Of one thing we can be certain on quality is what makes the difference between things being excellent or run-of-the-mill. Increasingly, quality makes the difference between success and failure.

Education is recognizing the need to pursue it as well, and to deliver it to pupils and students. There are plenty of candidates for the source of quality in 
education. Amongst these are: (1) outstanding teachers; (2) high moral values; (3) excellent examination results; (4) the support of parents, business and the local community; (5) plentiful resources; (6) the application of the latest technology; (7) strong and purposeful leadership; (8) the care and concern for pupils and students; (9) and a wellbalanced and challenging curriculum (Fraser, 2005).

Quality in much everyday conversation is used as an absolute-this is a thing of quality. The quality of something can be said to be a part of its nature. It is an ideal with which there can be no compromise. As an absolute, things that exhibit quality are of the highest possible standard that cannot be surpassed. Rarity and expense are two of the features of quality in this definition. Quality in this sense is used to convey status and positional advantage, and the ownership of things of quality sets their owners apart from those who cannot afford them. Quality is achieved by putting systems and procedures into operation and ensuring that those systems are efficiently and effectively operated. It is the audit trail approach to quality. Today much quality work is concerned with finding appropriate evidence about the way particular activities within the institution have been carried out. The procedural concept is about proving that things have happened in accordance with predetermined specifications. It ensures that activities conform to requirements, although critics of the approach argue that it can stifle creativity and innovation.

Hence, quality can be concluded as that which satisfies and exceeds customers' needs and wants. This is sometimes called quality in perception. Quality can be said to be in the eyes of the beholder. This is a very important and powerful definition, and one that any institution ignores at its peril. It is the consumers who make the judgements on quality (Pfeffer and Coote, 1991).

\section{Students as Customers}

Hussey and Smith (2010) furthermore explores that the rise of consumerism within education has had several effects but none have been more significant than those upon the students and their relationship to their universities and their lecturers. Against a background of an increasingly commercial and consumer-dominated culture, the provision of free higher education has been abandoned along with most maintenance grants. Many reasons are given for this, some more convincing than others, but the consequences are not fully appreciated. Now students enter education knowing that they are going to have to pay for it. They expect to take up loans and build up considerable debts in pursuit of a qualification that is getting more common by the year.

It is a significant consequence of these changes that students have come to see themselves as customers. Increasingly their perception is that they are "buying a product". This encourages an instrumental view of education: its value lies not in itself but in what it can be used to gain. An education that has to be purchased at great expense is purchased for a purpose, and that purpose is what it will earn. At the very least it must pay for itself. What that education contains and whether it is a coherent whole or just a collection of disparate pieces does not matter or at least the students will have difficulty in understanding why it does. What matters to the potential customer is the possession of a qualification. Knowledge, understanding and all the skills involved in critical thinking and analysis are valuable as a means to something else relating with the educational issues. 
As customers, students are now much more like their college friends who went straight out to work. When most students lived on a maintenance grant and had their tuition fees paid by the government there was a distinct condition of "being a student". Students as customers may be less willing to tolerate a shoddy "product". It is less willing to suffer poor teaching, sub-standard facilities, understocked libraries and appalling accommodation. If students are to seek work, then their timetables must permit them to do so. Timetables must be produced in plenty of time and designed to facilitate employment and childcare, so that working and mature students can organise their lives. The customers may reasonably demand that marking is done fairly and within a specified time, and that the feedback is of the right standard-although, as we have seen, what is actually demanded is not always what ought to be. So, in general, it is not implausible to claim that students as customers will, to use today's popular catch-phrase, drive up standards among universities.

Many universities have introduced elaborate student welfare systems, but these are even further from direct contact with students than the harassed teaching staff. This is almost certainly one of the reasons for students' discontent and dropout but, fortunately for those responsible for this situation, each intake of students has little knowledge of what previous cohorts enjoyed. It may well be that it is only this ignorance of what had gone before that has avoided more serious student unrest. In brief, if students are to see themselves as customers it is reasonable to demand that colleges are given the resources to answer this challenge.

The effect of students acting as customers may have even more farreaching consequences, whether or not universities have the resources to meet their demands. As the world has recently learned, a market is a capricious beast which will follow short term demands and fads, and go its own way irrespective of longer term consequences. Furthermore, the students also have a relationship with their lecturers which are very different from that which a customer has with the producer of a commodity or the provider of a service. One of the most serious consequences of students seeing themselves as customers is that it distorts the relationship between them. The academic who decides on what contribution is to be expected from the students and who judge the quality and quantity of the student's performance.

Academic must be able to forbid, and take disciplinary action against, plagiarism and other forms of cheating without fear of the litigation that a "customer" attitude may encourage (Baty, 2006b). Then, Hussey and Smith (2010) emphasizes again there may be increasing pressure on colleges to give the students some influence over their assessment and this may be particularly useful in formative tasks, but to the degree that this allows them to judge the quality of their performance, so the qualification will become less valuable and the assessment more pointless. For this reason it is inevitable that complaint procedures in higher education must make it very difficult for students to pass where they have been failed, increase their marks or improve the grade of their final degree. Mistakes may be made, so there must be mechanisms of reparation, but they ought not to become slot machines for dispensing degree certificates.

Education is a complex series of experiences; it involves interaction with others and with ideas, artefacts and processes, and these have to be experienced tobe appreciated and understood. They cannot be seen while casually window shopping for a qualification. Often what is not greatly valued 
initially will, with experience and time, come to be conceived of as being significant and a positive contribution to the individual's success and happiness. Each intake will have unique experiences depending on the cohort, changes in the educational institution and developments in the subject they are studying.

A proper education at university level does not just consist of giving knowledge or even understanding. This may be true in any other universities or colleges, often driven by the need to guide students through numerous tests, while the lecturers have succeeded when their students can repeat what materials have been taught. However, in education, competing institutions cannot make many of the changes that their "customers" may desire. They can improve facilities, engage better lecturers and so on, but such things as reducing standards, excluding difficult material, and reducing the burden of assessment, not only make them vulnerable to censure, but are ultimately self-defeating because it reduces the value of what the student achieves. Some colleges have reduced their entry requirements to entice in more students but there are disadvantages in doing so: the burden on the institution can increase if the students lack the usual skills and abilities, and the league tables will show if the number of completions and the levels of achievement fall. But again, Hart (1997) views that these practical difficulties are less important than the central point: ultimately, the purpose of a higher educational institution is not to satisfy its customers but to give them a good education, and that is not to be judged primarily by the customer. Therefore, according to Hussey and Smith (2010), it may be that in the long run the whole community must decide what constitutes a good education, but that task cannot and ought not to be given to the "customer" at point of purchase.
The students' relationship to a university is, or should be, even more like that of a citizen to a state. There are rights and duties on both sides, and loyalty and service on both sides too. The whole institution depends on a mutual engagement in activities beneficial to all and knitted together by trust: albeit trust that is backed up by sanctions and penalties. A reasonable level of education is essential to function as a citizen and everyone should feel that they have equal rights to learning, and that only relevant educational reasons should limit their progress, not their ability to pay. In return the universities can expect students not to squander expensive resources supplied by society. Turning this into a commercial transaction conducted in a marketplace has been a political folly which will tend to undermine proper education and may become "a social cancer".

\section{Quality control and quality assurance}

According to Sallis (2002), quality control is the oldest quality concept. It refers to the detection and elimination of components or final products that are not up to standard. It is an after-the-event process concerned with detecting and rejecting defective items. As a method of ensuring quality it may involve a considerable amount of waste, scrap and reworking. Quality controllers or inspectors usually carry out quality control. Inspection and testing are the most common methods of quality control, and are widely used in education to determine whether standards are being met.

Quality assurance is different from quality control. It is a before and during the event process concerned to prevent faults occurring in the first place. Quality assurance is about designing quality into the process to attempt to ensure that the product is 
produced to a predetermined specification. Put simply, quality assurance is a means of producing defect- and fault-free products. The aim in the words of Crosby (1984; Sallis, 2002) calls as the 'zero defects'. Quality assurance is about consistently meeting product specification or getting things right first time, every time. The quality of the good or service is assured by there being a system in place, known as a quality assurance (QA) system, that lays down exactly how production should take place and to what standards. Quality standards are maintained by following the procedures laid down in the QA system. Quality assurance is the responsibility of the workforce, usually working in quality circles or teams, rather than the inspector, although inspection can have a role to play in quality assurance.

\section{PRODUCT \& SERVICE STANDARDS}

Conformance to specification

Fitness for purpose or use Zero defects

Right first time, every time

\section{CUSTOMER STANDARDS}

Consumer satisfaction

Exceeding customer expectations

Delighting the customer

\section{Figure 1. Quality Standards}

Quality assurance involves moving with changing customer expectations and fashions to design products and services that meet and exceed their expectations. Only by delighting customers will they return and tell their friends about it (this is sometimes called the sell-on definition of quality).
The perceptions and expectations of customers are recognized as being short term and fickle, and so organizations have to find ways of keeping close to their customers to be able to respond to their changing tastes, needs and wants.

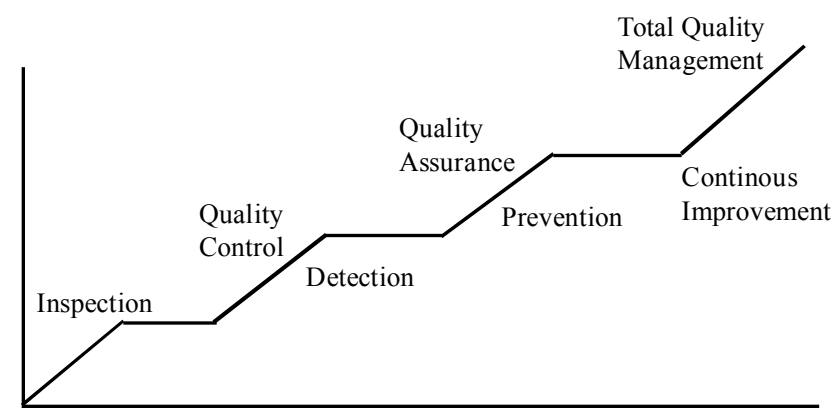

Figure 2. The hierarchy of quality concepts

\section{CUSTOMER SATISFACTION MEASUREMENT}

Customer satisfaction research literature traditionally agrees that service quality is a measure of how well the service level delivered matches customer expectations. Delivering quality service means conforming to customer expectations on a consistent basis. However, clearly, the fact that expectations are confirmed is not always sufficient for satisfaction. The results of a customer satisfaction measurement program cannot be expected to drive transit agency service improvement plans unless the findings correlate with agency-based performance measures, i.e. that data which the agency collects on a regular basis to document service performance. Customer perspectives must also be validated or understood by frontline transit agency employees if corrective action plans are to translate into successful implementation.

Hence, the customers' perspective, as measured, must be effectively communicated to agency personnel. This communication should facilitate management's use of customer feedback in 
determining which service improvements require immediate attention, which require further monitoring, and which indicate a need for educating customers about service parameters. For while customers must always be first, customers may not always be right. A fully diagnostic approach to customer satisfaction measurement is essential, rather than reliance on ratings and ranking of service attributes alone.

Customer satisfaction indices, or well-known as CSIs, are determined from benchmark and tracking customer surveys. These indices rely on measuring the impact of customers' ratings of individual service attributes on overall satisfaction with service. Several quantitative survey analysis techniques for this measurement are in use within transit and other service industries. These include

quadrant and gap analysis, factor analysis and multiple regression analysis, and

scatter grams. Of these, only factor and regression analysis can provide

quantitative benchmarks for continuous tracking, but problems are inherent. These

include the need for large sample sizes; the complications of explaining variability and weights, and reduction of potentially rich individual service attribute findings into results for aggregated dimensions-with fewer relevancies for specific transit improvements and performance measures (TCRP, 1999).

\section{Customer Satisfaction Planning}

Customer Satisfaction Planning (CSP) employs a combination of techniques, which results, as its name says, in customer satisfaction. Individually these techniques may be of little benefit, but the combination delivers the best product, more quickly and at least cost. CSP is the best if all these techniques are used (Hirata, 2009). Hill, Self and Roche, 2002 pointed out that customer satisfaction is based on meeting or exceeding customers' requirements. To achieve this you have to organise the business to ' $d o$ best what matters most to customers'. A customer satisfaction measurement programme will provide the information you need to maximize the beneficial financial effects of having satisfied and loyal customers.

Customer satisfaction measurement will enable you to accurately identify customers' requirements and their relative importance; understand how customers perceive your organisation and whether your performance meets their requirements; identify PFIs (priorities for improvement) - areas where improvements in performance will produce the greatest gain in customer satisfaction; pinpoint 'understanding gaps' where your own staff have a misunderstanding of customers' priorities or their ability to meet customers' needs; set goals for service improvement and monitor progress against a customer satisfaction index; increase profits through improved customer loyalty and retention.

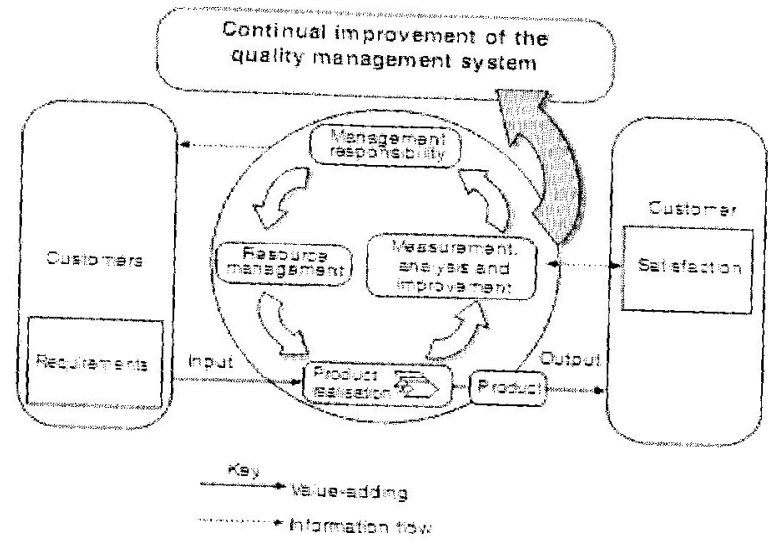

Figure 3. Model of a process-based quality management system (Hill, Self and Roche, 2002). 
Figure 3 summarizes from the standard that shows customers as the starting point of the quality management system. The role of management is to ensure that customer requirements are determined and are met with the aim ofenhancing customer satisfaction. Management is also responsible for making available adequate resources to enable the organisation to develop and deliver a product (the standard uses 'product' to mean product or service), which will meet those customer requirements. To judge the organisation's success in achieving this core objective, customer satisfaction will have to be measured and the results used as a key ingredient for the continual improvement of the quality management system. This type of Plan-Do-Check-Act (PDCA) process is a continuous one, creating the need to identify customer requirements and measure customer satisfaction on a regular basis.

\section{The educational product}

It is always necessary to ask two fundamental questions when trying to understand quality in any situation. The first is 'What is product?' The second is 'Who are the customers?' These questions are equally applicable to the discussion of quality in education. The product of education is an area of difficulty. There are a number of different candidates for it. The pupil or the student is often spoken about as if they fulfil that role. In education we often talk as though learners are the output, especially with reference to the institution's perceived performance over discipline and behaviour. Fisrtly, the terms like 'the supply of graduates' make education sound like a production line with students emerging from the end of it. The problem with this definition is that it is difficult faculty to square it with much educational practice. For a product to be the subject of a quality assurance process the producer needs firstly to specify and control the source of supply.
Secondly, the 'raw material' must pass through a standard process or set of processes, and the output must meet predetermined and defined specifications. Such a model does not easily fit education, although there are those who might wish it would. Such a model would clearly require an initial selection of students to be made. The processes such as the national curriculum and the specification of standards and competencies in National Qualifications (NQs) have improved the standardization of the process; nevertheless the process of education is anything but uniform. It is impossible to produce students to any particular guaranteed standard. As Gray (1992) has put it in his very useful discussion of the issue:

Human beings are notoriously non-standard, and they bring into educational situations a range of experiences, emotions and opinions which cannot be kept in the background of the operation. Judging quality is very different from inspecting the output of a factory, or judging the service provided by a retail outlet.

The idea of the learner as the product misses the complexities of the learning process and the uniqueness of each individual learner. What then is the product? Rather than answer this directly it is more helpful to view education as a service rather than a production line. The distinction between a product and a service is important because there are fundamental differences between them that have a bearing on how their quality can be assured.

\section{Education and its customers}

We have defined education as a provider of services. Its services include advice, tuition, assessment and guidance to pupils and students, their parents and sponsors. The customers-the stakeholders of the service-are a very diverse group and need identifying. If quality is about meeting and exceeding customer needs and wants, it is important to be clear 
whose needs and wants we should be satisfying. It is important to say something about the idea of a 'customer' in the context of education. To some educationalists 'customer' has a distinctly commercial tone that is not applicable to education. They prefer to use 'client' instead. Client, with its connotations of professional service, is seen as more appropriate. 'Stakeholder' is another term often used in this context. Others reject all such language and would rather stay with 'college student'.

Some people would make a distinction between clients, who are the primary beneficiaries of the education service, and customers, who pay for it but who may be once removed, such as parents, governors, employers or government. The diversity of customers makes it all the more important for educational institutions to focus on customer wants and to develop mechanisms for responding to them. It can be helpful to make distinctions between: (1) primary customers, who directly receive the service; (2) secondary customers, such as parents, governors, sponsoring employers of vocational students, all of whom have a direct stake in the education of a particular individual or in a particular institution; (3) tertiary customers, who have a less direct but nonetheless crucial stake holding in education, such as future employers, government and society as a whole; and (4) internal customers, who are the employees of the institution and who have a critical stake holding in the organization's success.

The needs and views of the various customer groups, whether they are internal or external, do not always coincide, especially in large and complex institutions, although the conflict can equally be present in small ones. Potential and actual conflicts of customer interest will always exist. One of the best methods of resolving different interests is to recognize their existence and to look for the core of issues that unite the various parties. All stakeholders need to have their views listened to and to be treated fairly. Quality and justice go hand in hand. This is particularly the case when dealing with complaints, which are instances of those critical incidents where it is possible to judge how committed an institution is to a customerfirst approach.

It is often difficult to ensure that the primary customers' views are paramount. There are strong forces pulling against it, not least those that can be exerted by funding processes and mechanisms. Where the needs of the learner and funding mechanisms collide, it is very difficult for an institution to put its learners first. This is particularly the case where funding mechanisms emphasize efficiency that can only be achieved at the cost of quality. For example, a staffing cut may lead to higher college studentslecturer ratio; or a funding cut may lead to a reduction in service that may not accord with what customers are feeding back.

\section{The quality of learning}

Education is about learning. If the quality management is to have relevance in education it needs to address the quality of the learners' experience. Unless it does that, it will not make a substantial contribution to quality in education. In a period when most institutions are being asked to do more with less, it is important that they focus on their prime activitylearning. Students learn best in a style suited to their needs and inclinations. An educational institution that takes the total quality route must take seriously the issue of learning styles and needs to have strategies for individualization and differentiation in learning. The students are the primary customer, and unless learning styles meet individual needs it will not be 
possible for that institution to claim that it has achieved total quality.

Educational institutions have an obligation to make learners aware of the variety of learning methods available to them. They need to give learners opportunities to sample learning in a variety of different styles. Institutions need to understand that many learners also like to switch and mix- ' $n$ '-match styles and must try to be sufficiently flexible to provide choice in learning. A start can be made with the learners and their lecturers establishing their 'mission'. This could be 'All Shall Succeed'. From this, negotiation might take place about how the parties will achieve the mission-the styles of learning and teaching and the resources they require.

Individual students should negotiate their own action plans to give them motivation and direction. The process of negotiation may require the establishment of a quality steering committee or forum to provide feedback and to give the learners an opportunity to manage their own learning. Parents or employers might well be represented on it. Both teachers and students can ensure that all are on track by undertaking detailed monitoring through progress charting. This is important to ensure that timely and appropriate corrective action can be applied if there is a danger of failure. The establishing of a strong feedback loop is an important element of any quality assurance process. Evaluation should be a continuous process and not just left until the end of the programme of study. The results of evaluation processes should be discussed with the students, perhaps by means of completing a record of achievement. The very act of being involved in evaluation will assist in building up the students' analytical skills.
Therefore, it is important that the institution uses the results of the formal monitoring to establish the validity of its programmes. It must be prepared to take the necessary corrective action if the customers' experiences do not meet their expectations. None of this is easy, as lecturers who have pioneered such processes know. It can be an emotional experience and one that can take unexpected turns. What it does is to provide students with motivation and the practical experience of the use of quality management tools that are transferable to other situations (Sallis, 2002).

\section{CONCLUSION}

The poor quality causes in Higher Education (HE) are directly attributable to an organization's behaviours or attitudes in dealing with the customers or stakeholders. They are often from lack of leadership, care or courtesy. Meanwhile, the other supporting problems corncern with the lack of training or coaching will be the principal reasons for a breakdown of service. There is a close relationship between the customers and the persons who deliver the service. The service cannot be separated from the persons delivering it or from the persons receiving it. Every interaction is different, and the customers in part determine the quality of the interaction. The quality of the service is determined both by the persons delivering and the persons receiving the service. There can be no absolute consistency or homogeneity in service delivery. The consistency of the service can only be within boundaries. Services face the problem of intangibility. It is obviously difficult to describe to potential customers exactly what is being offered and equally difficult on occasions for customers to describe what they want from the service. Services are largely about process 
rather than products. It is usually more important how an outcome is arrived at than what the outcome is. In relating with the service issues, therefore, the only meaningful performance indicators are those of customer satisfaction. Intangibles or soft measures are frequently regarded as the importantthings to success and to the customers as are hard and objective performanceindicators. Soft indicators, such as care, courtesy, concern, friendliness and helpfulness are often uppermost in customers' minds. The consumers will judge service quality by comparing their perceptions of what they receive with their expectations of it. Much of this is still largely happened for education sector, particularly in Higher Education organisations.

\section{REFERENCES}

Baty, P. 2006b. Litigation Fears Lets Cheats Off the Hook. The Times Higher Education Supplement, No. 1,764, 13th October, p. 56.

Brennan, J \& Shah, T. 2000. Managing Quality in Higher Education: An International Perspective on Institutional Assessment and Change. Buckingham: Open University Press.

Fraser, K. 2005. Education Development and Leadership in Higher Education: Developing an Effective Institutional Strategy. Oxon: Routledge Falmer.

Gray, L. 1992. Foreword to Edward Sallis and Peter Hingley, Total Quality Management, Coombe Lodge Report, Vol. 13, No. 1, The Staff College, Blagdon, Bristol.
Hart, W. A. 1997. The Quality Mongers. Journal of the Philosophy of Education. Vol. 31, No. 2, pp. 295-308.

Hill, N, Self, B \& Roche, G. 2002. Customer Satisfaction Measurement for ISO 9000: 2000. Oxford: Reed Educational and Professional Publishing Ltd.

Hirata, T. T. 2009. Customer Satisfaction Planning: Ensuring Product Quality and Safety within Your MRP/ERP System. New York: Taylor \& Francis, LLC.

Hussey, T \& Smith, P. 2010. The Trouble with Higher Education: A Critical Examination of Our Universities. New York: Routledge-Taylor \& Francis Group.

Ross, K. N \& Genevois, I. J. 2006. Cross-National Studies of the Quality of Education: Planning Their Design and Managing Their Impact. Paris: UNESCO.

Shattock, M. 2006. Managing Good Governance in Higher Education. New York: Open University Press.

Pfeffer, N \& Coote, A. 1991. Is Quality Good For You? Social Policy Paper Number 5. London: Institute of Public Policy Research.

Sallis, E. 2002. Total Quality Management in Education (3rd Ed.). London: Kogan Page Ltd.

Transit Cooperative Research Program (TCRP). 1999. A Handbook for Measuring Customer Satisfaction and Service Quality. Washington DC: Transportation Research Board National Research Council. 